Int. J. Dev. Biol. 53: 1277-1290 (2009)

doi: $10.1387 / \mathrm{ijdb} .072384 \mathrm{ag}$

\title{
Ontogeny of an adventurous mind: the origin of Antonio García-Bellido's contributions to developmental genetics
}

\author{
ALAIN GHYSEN* \\ Laboratory of Neurogenetics, INSERM U881, Montpellier, France
}

\begin{abstract}
This interview with Antonio García-Bellido explores three aspects of his work. First and foremost is the origin of his contributions: trying to define what allowed him to become a pioneer of developmental genetics. The second part deals with the nature of his major contributions, as seen by himself. In a third section he expresses his views on a number of subjects that relate mostly to the future of developmental biology and to evolution. A list of his most significant publications is appended as an annex.
\end{abstract}

KEY WORDS: developmental genetics, drosophila, evolution, clonal analysis, history of science

\begin{abstract}
The difficulty of translating from a language that doesn't yet exist is considerable, but there's no need to exaggerate it.

Ursula K. Le Guin - "Always coming home"
\end{abstract}

\section{Introduction: the roots of discovery}

The essential contributions of Antonio García-Bellido to developmental genetics are widely recognized, and in 1998 the Int. J. Dev. Biol. published a Special Issue entitled Developmental Genetics of Drosophila that was dedicated to him (see: http:// www.ijdb.ehu.es/web/contents.php?vol=42\&issue=3). In addition to review and research articles, the 1998 Special Issue also contained a number of personal testimonies by F. Jacob, E.B. Lewis, P. Lewis (in the form of a poem), R. Nöthiger, J. Merriam, F. Kafatos, among others. The aim of the present interview is not, therefore, to give one more account of Antonio's impressive achievements. Rather, I was interested in the reasons why this man, having no better tools nor better information than hundreds or thousands of others, managed to pioneer a whole field: the genetics of animal development.

I have always felt perplexity at the ability of a few to see what was there to be seen by everyone: Gregor Mendel, Charles Darwin, Isaac Newton, to name but a few. But I never had the opportunity to ask any of them what had led them to such heights of insight. I was therefore extraordinarily happy, as well as surprised, when Juan Arechaga, Editor-in-Chief of the Int. J. Dev. Biol. asked me if I would be willing to interview Antonio García-
Bellido on the occasion of this Special Issue about Developmental Biology in Hispania. This gave me some sort of authority to push the discussion beyond its ordinary limits and try to uncover the roots of Antonio's insights.

Very early on, Antonio decided to become trained in a field that was not practiced in Spain at the time - a field that, actually, did not exist yet. How can one decide to work in a non-existent field? This was the major question that underlied this interview. In retrospect the interview was closer to a cross-examination than to a normal discussion. I would repeatedly come back to the same questions, tracing minute discrepancies to see if they would reveal some hidden truth, and I must thank Antonio for his patience and willingness to help me. After several hours of questioning, we finally uncovered part of the explanation, very unexpected in a sense, but very fitting as well. What I learned made me (even more than before) proud of being a scientist, for the searching mind is truly our most powerful, beautiful and fragile gift.

I subsequently edited the transcripts (270 $\mathrm{min}$ ) in terms of reorganizing and selecting the sections that seemed most relevant to the subject, but I tried to keep Antonio's part as verbatim as possible, to keep the spontaneity and flavor of his answers. The first section deals with the origin of his far-reaching contribution. The second section summarizes his major achievements and discoveries. A third section, also based on the interview, outlines his present views about various questions, including teaching, development and evolution. A selection of important papers can be found in the References section at the end.

\footnotetext{
*Address correspondence to: Alain Ghysen. cc103 USTL, Place E. Bataillon, 34095 Montpellier, France. Tel: +33-467-144-802. Fax: +33-467-143-928. e-mail: alain.ghysen@univ-montp2.fr Web: http://www.neurodvpmt.univ-montp2.fr
}

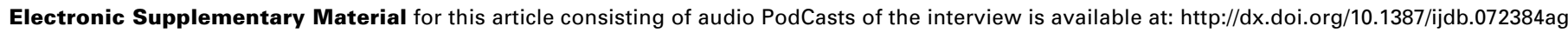

Final author-corrected PDF published online: 17 November 2008. 
More personal aspects of Antonio's life, including the unrestricted support and contributions of his late wife, Maria-Paz Capdevila, have been covered in several excellent interviews (see Aznarez, 2006; Garcia-Bellido, 1988; Mendez, 1999). These interviews also deal with less scientific matters such as his impressions about the current state of Spanish universities, his concerns about the Spanish research system, or his views about other aspects of society. None of those aspects have been dealt with here, not that they are not interesting - quite the opposite but they did not seem to fit as easily in a scientific journal.

\section{Ontogeny of an adventurous mind}

\section{Early education}

You were born into a family of distinguished academics: your father was a well known archaeologist, and your maternal grand-father a Latin philologist.

Yes, I grew up in an atmosphere of academic interest with a special emphasis on humanities. My father and maternal grandfather were both members of the Spanish Academy, and my mother was professor of Greek at the University. My father was not involved in politics at all, in contrast to my grandfather, who was one of the leaders in fighting the dictatorship of Primo de Ribera - he was apparently a pain in the neck for the authorities!

With this strong background in humanities, how is it that you developed a taste for science very early on?

My father was a very educated and curious man. Not only had he a wide interest in history, which he transmitted to me, but he also had a fantastic library of divulgation books, which I read assiduously when I was in my teens. Books on physics, astronomy, mathematics, biology... He encouraged my interest, and when I told him that I was more interested in science than in humanities, he was very happy. In fact he told me once that he would have liked to choose biology himself. On some occasion he gave me as a present the famous Allgemeine Biologie by Hartmann (I could read German at that time). I also remember a book with an emphasis on development - I don't remember the author's name - which fascinated me: the origin of animals and how they develop. It was purely theoretical, but these authors searched for an interesting problem, and that motivated me.

\section{In parallel to your reading you also did experiments.}

There was a coal room in our house, and I converted it into a lab to keep and observe aquatic animals and do dissections and things like that. But I was not a naturalist in the classical sense, I had no interest in the animals per se. The culturing and observation of animals, of little arthropods and larvae, was part of the curiosity stimulated by the books I was reading. I was more interested in the questions, in the problems, in the theory if you want, than in actual experiments. The observation was to inform myself, to get acquainted with variation, with the biological world.

You were so interested that you built your own microscope at age 16!

I built it because my father did not want to give me one. He did not want this to be converted into a toy, and he said: if you want to have one, try to make it yourself. Therefore I constructed a
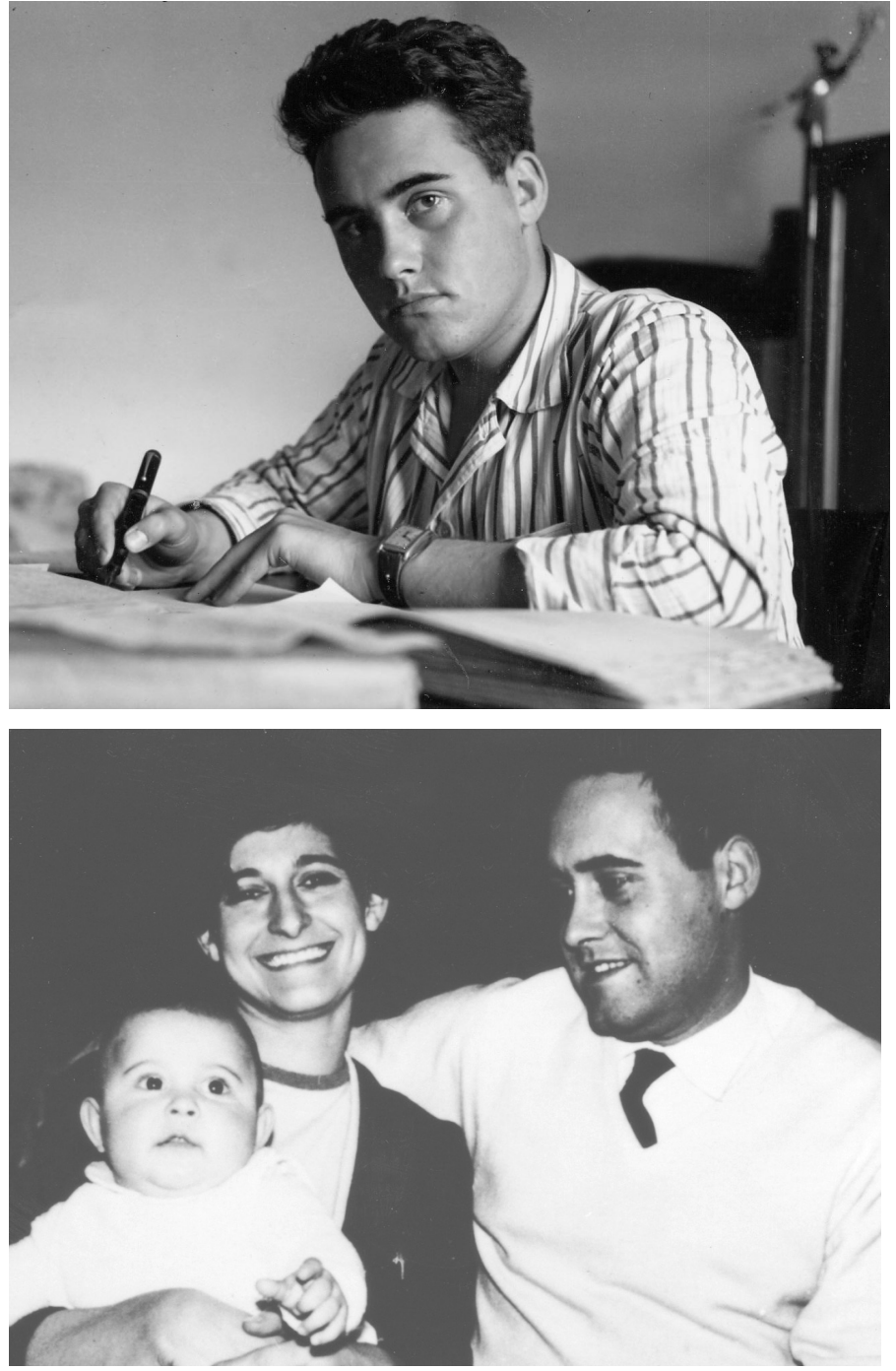

Fig. 1. Antonio Garcia-Bellido in 1956, aged 20. Picture taken by his father.

Fig. 2. With Maria-Paz and their first son, Antonio, in Zürich (1963). Picture communicated by Diego, the third of their four children, now a distinguished paleontologist.

compound microscope by myself. It was horrendous in terms of aberrations, but it was very stimulating. My father's stimulation was of the silent, quiet type. At the end of high school I was clearly decided to study biology, in particular the biology of development. My family would have preferred me to study medicine or agronomy, as they were afraid biology would not support me, but my father never tried to change my decision.

\section{Your father was also a good painter - may this have influ-} enced you?

My father's painting was mostly analytical; it was professional painting, although he also had his own frivolities and liked to do landscape watercolors. In fact he made use of that in his career enormously. I think he went to archaeology because he was interested in art and the history of art. He was a very sensitive 
man, in a positive way. The feeling I received from him as a painter is the feeling of plastic art, the feeling of things that exist in the world and are self-contained, are solid, are expressive, are colorful.

\section{Studies}

You grew up in the aftermath of the Spanish civil war. How did it affect your studies?

Franco disliked intellectuals, he feared them because they have arguments - not simply opinions. The majority of the University professors used to be Republicans and they were substituted when he came to power, substituted by very incompetent persons that were put in as professors in the university - just like that. On the other hand, since it was impossible to do any politics, we devoted all our time to reading and discussions. With a group of friends of different disciplines, we met once a week to contrast our visions and exchange our opinions of the world.

\section{Did you like high school?}

I keep happy recollections from this period. The teachers were young and inexperienced, but very enthusiastic. Some of the professors made us present talks to the other students, to force us to digest and to synthesize our readings. I don't think I made any particular discovery during this period, except that I realized I had to train myself exactly as I did with languages. I needed a language, and I would think to myself well let's go there and work it out!

\section{University turned out to be more disappointing...}

The professor of genetics, Antonio de Zulueta, was a learned person; he even spent a few months in the lab of T.H. Morgan in 1930. At the end of his course, he gave an exam which I considered I had done very well because I had read a lot of books, I mean five, six, on genetics, whereas his lectures were just dictated-I don't think he ever went beyond Mendel's third law. After the exam was over, he called me and said my exam was to be flunked because I had believed that I could educate myself. For him the role of the students was simply to learn what your teacher tells you, like in medieval times. This was my first experience of genetics in the University: I was horrified!

\section{His was not the only course that bored you?}

University was a long and heavy period. Themes were obsolete, courses were dictated, and professors taught a lifeless biology, a biology of lists and classifications. They were so boring that I stopped attending classes altogether. In third year I went to a lab during the afternoons. This was the lab of Eugenio Ortiz. He was working on genetics, which I thought was a powerful tool to enter the arcanes of developmental biology. In my fourth and fifth years I would spend all my time in this lab.

\section{Thesis}

You decided to do a thesis in the laboratory of Ortiz. Did he supervise your work closely?

Oh no, he did not care about it. Ortiz was working on mutagenesis and he had just obtained a series of alleles on the X chromosome. An allelic series with half lethals, total lethals, and I said well, let's explore it - using all the available techniques, reading Hadorn, just getting acquainted, putting my mind in a mess. My interaction with Ortiz was nil! I was just working in his lab and that was it.

\section{But was he interested in your work?}

The only thing I know is that I produced one thing, which is the analysis of the sensitive period for mutations in spermiogenesis, and he wanted to publish the paper with his name and I said No, this is my work and / will not give it to you. I was still doing my PhD and this was a problem because he was going to throw me out of the lab, and then some friends of his said No, you cannot do that, you have to yield and let him. Ortiz did not teach me anything, he did not even read my thesis - but it was the only place where I could do what I wanted.

\section{Did your father keep an interest in your biological work?}

I remember coming from the lab late in the evening and having dinner alone and he would just sit in front of me and ask me how things were going. He could not understand the details, but he was simply encouraging me to do science and putting in me the feeling of respect and professionalism and seriousness which he

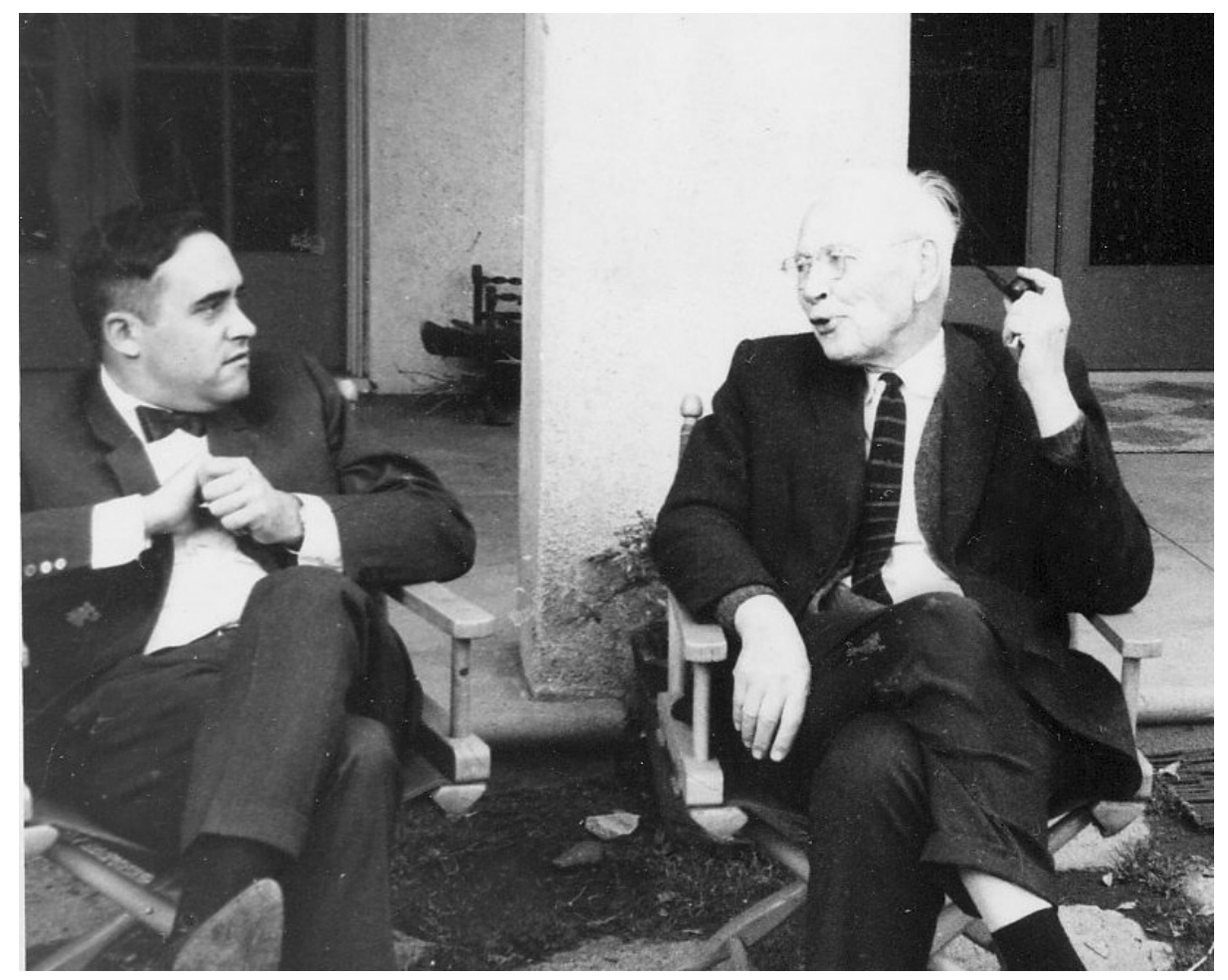

Fig. 3. At Caltech, discussing with Sturtevant (1967). Picture taken By Eric Bahn 
himself had applied to all his work.

Retrospectively, what made you decide to concentrate on the genetic approach to development?

The thing that most interested me was the evolution of an embryo, but the classical perturbations used at the time were just with a scalpel, changing pieces and I realized that this was a bit too superficial, that the actual guide to development must be the genes. This came to me very early, through reading again. I remember a very good book by Waddington, where he put emphasis on the analytical power of genetics. I believed at that time, very early indeed, that the role of genes in the control of development was profound, was in the deep structure of the system. The idea that the terms in which development could be positively described were genes is a very early - not a finding, but rather, a very early conclusion on my side, yes.

\section{Stays abroad}

After you completed University, you did physiology with Wigglesworth at Cambridge before you began your thesis work; and after the thesis you learned cell biology with Hadorn in Zürich, and finally genetics with Ed Lewis at Caltech. Why did you not go straight into genetics?

Because I needed physiology and cell biology as well as genetics! I wanted to prepare myself, to get acquainted with the problem. Development is not an easy thing, and I needed a context. You cannot simply go there and start analyzing mutants: you have to know more things in order to interpret the effect of mutations. Physiology first, because it's the context in which things occur.

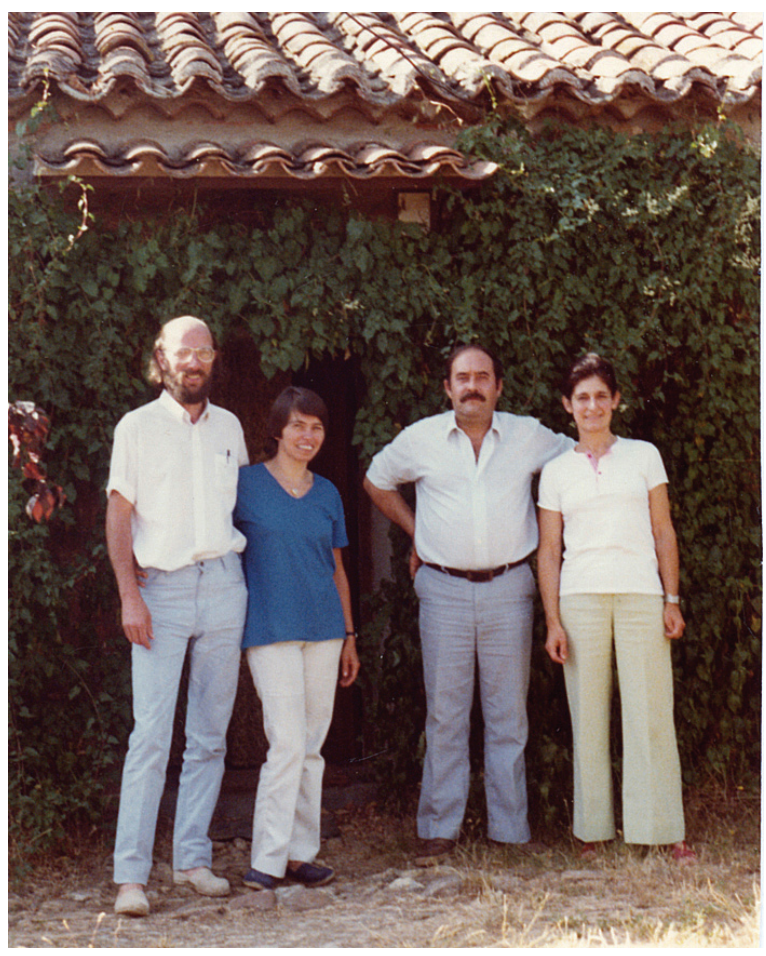

Fig. 4. In front of Maria-Paz and Antonio's house in Viñuelas, near Madrid (1981). From left to right: Alain Ghysen, Christine DamblyChaudière, Antonio Garcia-Bellido and Maria-Paz Capdevila. Self-timer.
You have to learn about hormones, you have to learn about the physiology of the growth of imaginal discs or of organs, so you have to go through a very descriptive, although a very experimental, aspect.

You give the impression that it was all very well planned. As a matter of fact I remember that I had a program: I am going to learn this first, other things second, this is going to take me some years but I am going to go step by step, and then I was very fortunate; because of my work in Hadorn's group, I won the recognition of Caltech and they awarded me a fellowship.

\section{What was thought of the role of genes at the time?}

The mentality was - genes do not exist! The things we have are mutations, mutations that perturb things, and therefore you can spend a lot of time in describing the phenotypes of mutants in different conditions. It is a pure, very superficial description, that is what genetics was at the time. Mutations are responsible for evolution, but after all it may be that their effect is completely by accident and that genes have nothing to say, that they are irrelevant, that nothing is to be expected but a chain of effects that ends up having a morphology. The notion that genes play a role in development, the positive feeling that the crucial thing is what the genes are doing, I learned that by sheer experience in Caltech.

But we have a problem here. You knew that you had to learn physiology to understand what the genes are doing, several years before you acquired the notion that genes play a role in development, at Caltech?

I see your point - but this is the way it was. You have to realize that I had almost no experience in the real world, what an animal is, so I had to learn. I did not know that genes were going to be relevant in development before doing all these things. I was confronted with this world step by step, not with a foresight of what is going to be at the end. I had to pass through this period of education. During my early education I wanted first of all to get informed, to learn, to be filled with information, with points of view, with perspectives. But it is true that very early I programmed the three steps, which fortunately I succeeded in carrying out. Why? Well, because maybe all three were going to be important and I did not know which was the most important. But I knew that I had to go through it, and this I knew from my reading.

But this was not written anywhere! You present this as if it were obvious.

Well... no, it was not written anywhere. But for me it was very obvious. It was just the curiosity of knowing what we do know, which perspectives are there; the curiosity to know the world that I was going to be confronted with. I simply needed to have information on different aspects of development, right? And different aspects of development pass through physiology, the general control of development as a whole, the cellular level, and genetics - genetics at that time was no more than the construction of chromosome tools, and mutations.

\section{An organized curiosity?}

This is true. I believed from the very beginning that at the end, the more subtle and more profound descriptions were going to be at 
the level of genes. Not the genes, let's put it in the context of that time, rather, the mutants. The wealth of variation that you can produce with mutations is enormous, and maybe we wanted to explore that. We knew that the basis of this variation was the gene, which could therefore be a very profound reference.

The conclusion seems to be that you had no a priorimodels or ideas about development, or about your own training.

Right. The very original idea of having to be trained in physiology, in anatomy at the level of cells (particularly in imaginal discs), and in the powerful tools of genetics, this was produced through experience in these labs. But it was not present in these labs; rather, it was something that came from the experiments.

In retrospect, it seems difficult to discriminate between your own, in-

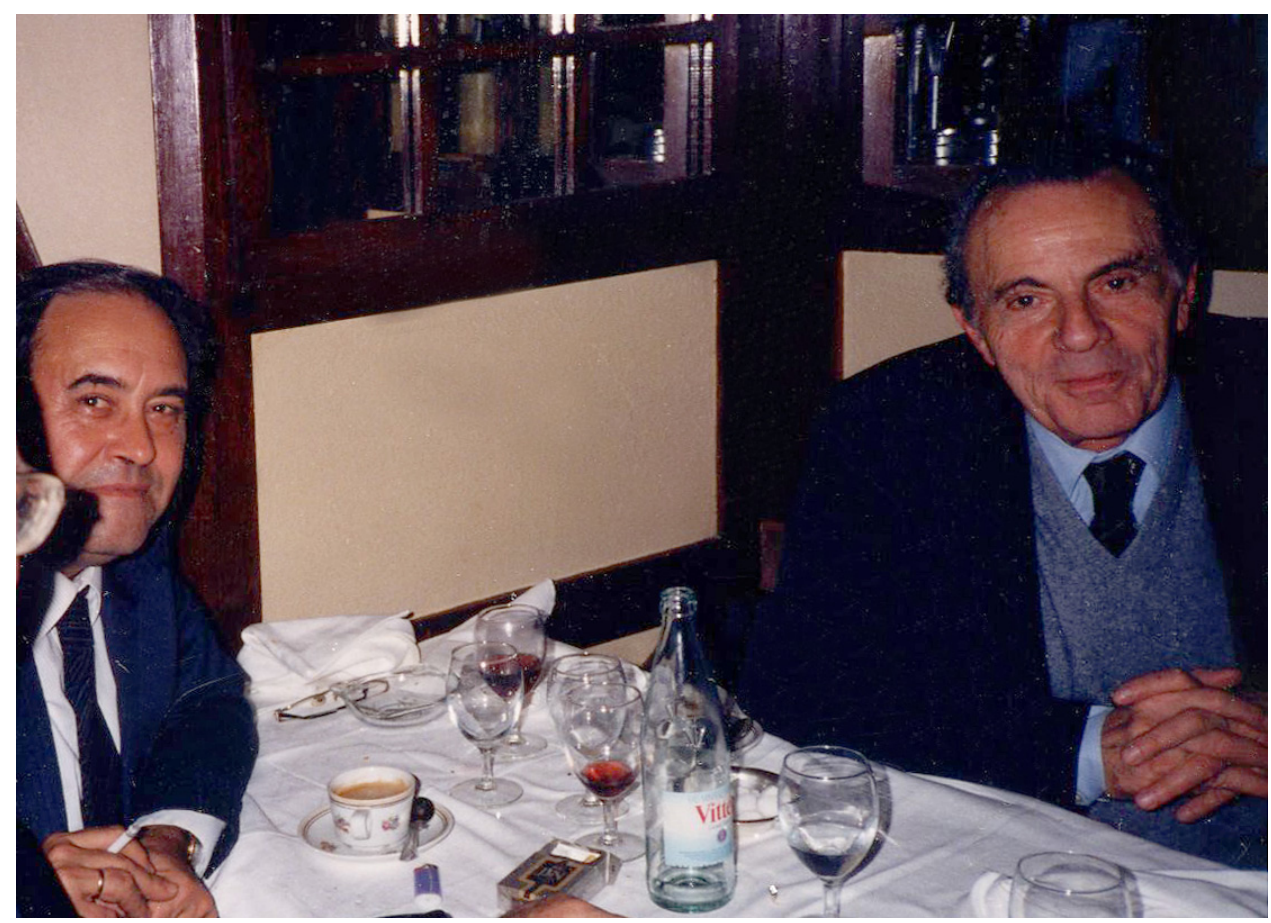

Fig. 5. With François Jacob in Paris, 1987.

trinsic, development and what was brought to you by your stays abroad?

Absolutely. I learned clonal analysis - the real one! - in Caltech. And the manipulation of the genome - these are instruments that I used very much later on. The same with Hadorn, for other reasons. You depend very much on the context. So, what if I hadn't been there at the time? Well, it's a mystery. I don't know. If I had not gone to Caltech, if I had stayed in Madrid - it's difficult to answer, but I would probably have done other things.

You mean that the essential role of your postdocs in your training was due to a specific interaction between you and these labs - that it was neither you alone nor the labs per se.

I would summarize saying that, yes. The fundamental change was the realization that development is a question of cells, and a question of genes - wild type genes. And this came from results that suggested more and more that most genes act cellautonomously, and that suggestion requires you to think about it, to produce - not models, but conclusions.

\section{Teachers}

You had essentially four teachers: Wigglesworth, Hadorn, Lewis and Sturtevant. Could you summarize what you received from each of them?

Those people not only represent an aspect of science, but also an atmosphere. What I learned in Cambridge was my first contact with a lab, with a decent University, with a way of thinking. This was my first experience with real research. I was not so alone in the world anymore. Learning by myself the transplantation technique told me that after all I was capable of doing things on my own. And scientifically speaking,
Wigglesworth, for reasons that I ignore, esteemed me highly.

\section{What did you learn from Hadorn?}

We had a different mentality. Already at the time, I thought that there were causes and effects and that whenever you have some results, you have to propose a hypothesis. But Hadorn was more of the let's see what happens type, which is very contrary to my mind. I learned, not so much from Hadorn, but because of the atmosphere again. This is where I began to use the cell dissociation and recognition experiments, which were crucial for the rest of my career. What I did learn, personally, is the fantastic individuality of cells, the fantastic amount of information in cells. So the experience in Hadorn's lab was a marvelous education for meit was the first time I mentally reached the world of cells.

At the time most of Hadorn's lab was working on transdetermination, yet you took a different subject. Was it because you wanted to be completely independent?

I was doing things that were my own, not just the work of others, or with others. But I had that to begin with. When I went to Cambridge I was independent, when I did my PhD I was independent, I had learned that already. In Hadorn's lab, I was completely independent all the time. Only Maria-Paz [Capdevila] helped me with the study of the development of the testis.

\section{Then you went to Caltech to the lab of Ed Lewis}

That was because I had observed in Zürich that in my cell recognition assay, homeotic transformations change the recognition properties of cells, as if the cells carried in themselves labels that define their affinity and histotype. But the homeotic mutations I used in Zürich were not neat - there was a lot of variability - and so I wanted to work on the well-defined bithorax system developed by Ed Lewis. Fortunately, he invited me to come to Caltech, 
I think via Hadorn. And I started to do dissociation experiments with bithorax, and mixing cells and trying to convince cells of the anterior region and cells of the posterior region to talk to each other - I was at the time full of the Spemann notion of inductive assimilation.

\section{But anterior cells did not talk to posterior cells...}

No! Even though they were in intimate contact, the anterior cells did not convince the posterior cells and vice-versa; and Ed told me one thing that illuminated my life, even though it was sort of a tautology. It is because anterior cells are bithorax ${ }^{+}$, he said, and posterior cells are postbithoraxt. This is, at the same time, a silly hand waving and very profound, because it means that genes are doing something in the wild type condition - and that was a revelation.

\section{How was your interaction with Ed?}

Ed was fantastic at genetic engineering. He taught me about chromosome construction, and I learned a lot from him, technically speaking. He was curator of the stocks at Caltech, the most extensive collection of mutants in the world, and I mounted all the mutants and looked at them under the microscope. That helped me a lot. Before that, mutants were only examined under the dissection microscope, so that brought me again to the microscopic level, which is the one I have never left since. But at the time, Ed was interested in pseudo-alleles, in gene structure, in funny aspects of gene function such as transvection, not so much in developmental phenomena.

Yet he was already interested in the function of the wild type alleles, doing cell autonomy experiments with chromosome loss.

Right. He showed that bithorax mutations behave in a cellautonomous way, and he did put emphasis on this autonomy. This is true. But this autonomy remained a curiosity for a while - a curiosity that turned out to be crucial, because it demonstrated that systemic changes like bithoraxoccur in cells, in the individual cells, and cannot be corrected during subsequent development.

\section{You also had a lot of interaction with Sturtevant..}

He was already very old at the time. He was a man with a more classical education than Ed. For Ed Lewis, words like determination, induction, morphogenetic fields and all the classical terminology was just blah blah, but not so for Sturtevant. Both of them had personal effects on me, but I praised Sturt's ideas more, his perspectives, his profound feelings.

\section{Mosaics: gynanders and clonal analysis}

\section{What was the origin of your groundbreaking work on gynanders?}

At Caltech, they had invited me to give a series of seminars about what was going on in Europe at the time. I mentioned the data published by Müller on gynanders, which suggested that some elements were determined early, and that the fly was a kind of mosaic. Then Sturtevant offered me his collection of about 300 drawings of gynanders he had obtained in $D$. simulans. John Merriam happened to be there as a post-doc and he immediately entered the work on gynanders (and on mitotic recombination, see below). John also taught me a lot of practical mechanical genetics that helped me very much.

Why did Sturtevant keep this collection of drawings for so long without getting to 2D fate mapping? After all, he was the one who had pioneered 1D-mapping of genes along chromosomes.

That is because for him there was confusion with cell determination. He thought that the presence and position of male $v s$. female territories indicated that the tissue was already determined. In fact, he worked a little bit on tergites, but then stopped; he did not follow up the idea. But actually, gynanders do not tell you anything about determination. The idea that you could use the data to fatemap the entire embryo - this is mine. That was a very stimulating moment, because gynanders provided a way of mapping the
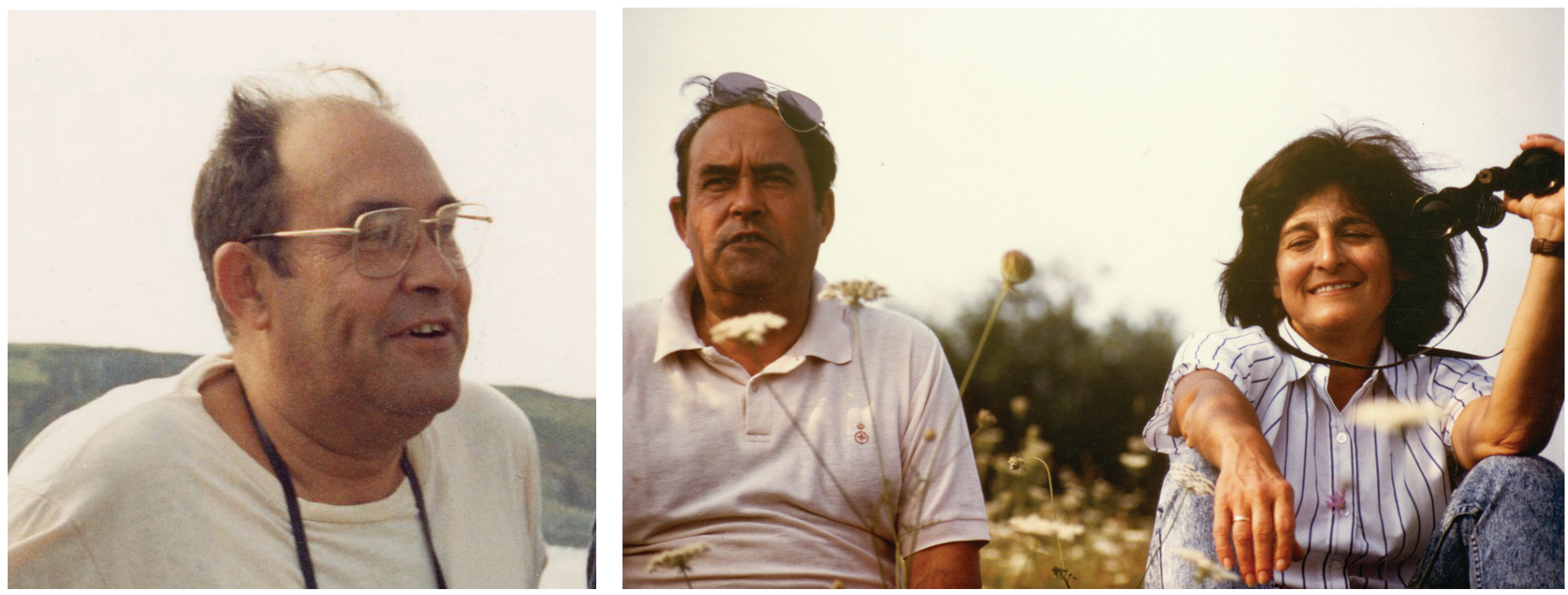

Fig. 6 (Left). At a meeting in Oviedo, 1988.

Fig. 7 (Right). Antonio and Maria-Paz at Figueiras, North of Spain, around 1990. Picture courtesy of Diego. 


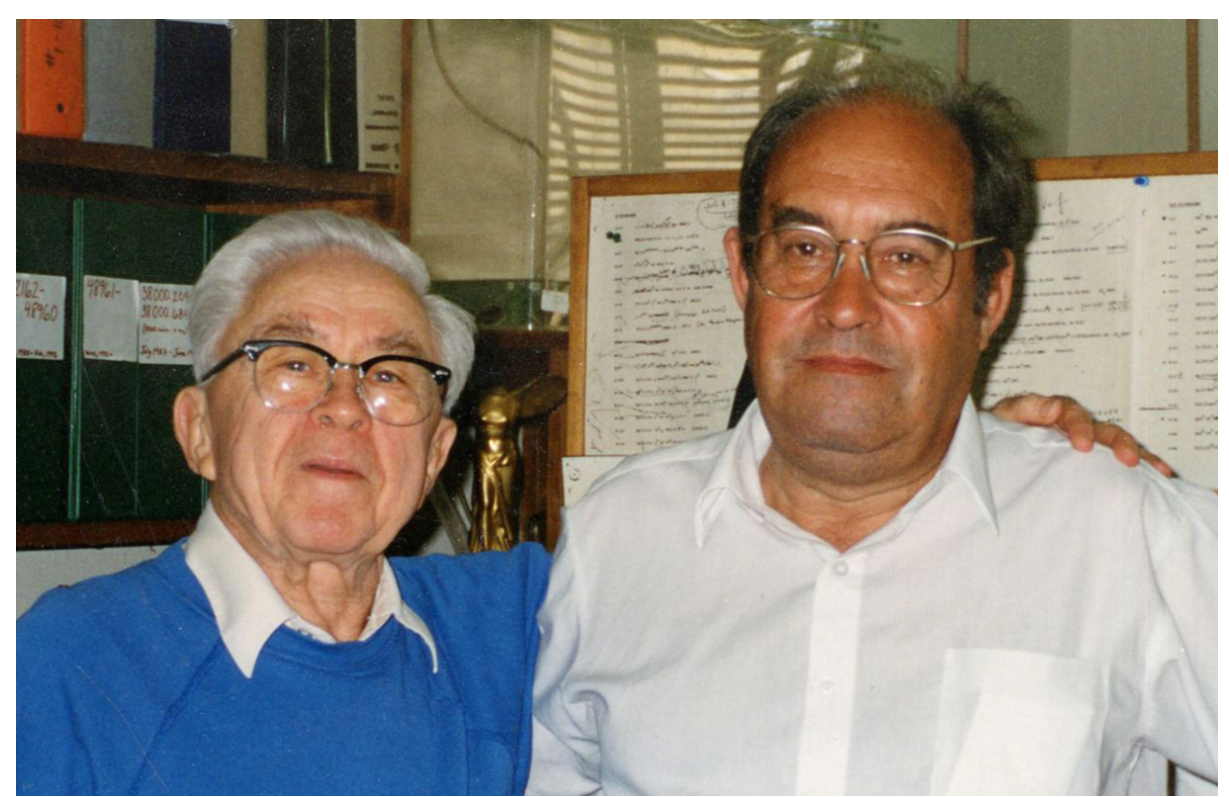

Fig. 8. With Ed Lewis, 1996. Picture taken by Sue Celniker.

black box at the beginning of development. Sturt followed the whole thing day by day - he was very excited!

Did the work on gynanders somehow lead to clonal analysis through mitotic recombination, which was to play such a crucial role in all your subsequent work?

No, it was independent. The conclusion from my dissociation experiments in Hadorn's lab was that certain cell types, for example the chaetae, were already determined in late larval imaginal discs. But this could not be, because according to the descriptions of Waddington, the cells in the wings of the pupae had to grow a lot still, and there cannot be a lot of growth if the cells are already fully committed. So the thing I did was to ask a medical doctor here in Madrid to get access to an X-ray machine just to irradiate series of larvae staged every 8 hours. The larvae were heterozygous for mwh, a fantastic cell marker that I had already used in the dissociation experiments in Zürich. I collected the resulting adult flies and brought them to Caltech. Then they invited me to give a talk in Chicago and I thought, I might as well have a look at that collection before going. I expected to have very few cases of $m w h$ homozygous spots because I knew from the work of Curt Stern that mitotic recombination is very rare. And I had the surprise to find spots by the hundreds, and that clone size decreased every 8 hours and so on, and THAT was, I would say, the real revelation of my life.

Did you see immediately all the implications of that finding? I remember when I saw that in Caltech, before the talk I gave in Chicago, I said: This is it!. This is the radiography of development - you can describe development at the level of cells, and other things start appearing because there were certain limits that the clones would not cross. Also the possibility of associating mutants with cell markers on the same chromosome to produce and analyze mosaics at the single cell level - the whole idea of clonal analysis and of studying the genetics of somatic cells was there.

Why did you decide to go back to Spain, having several possibilities of staying in the States, and knowing it would be more difficult in Spain?

The major component is that I missed Spain. Not so much the climate, because in Caltech the climate is similar, but the Spanish culture. And I wanted to see whether I was capable of setting up a lab by myself. When I arrived, I gave a series of seminars on my recent work and some students came to see whether I wanted to accept them and I said yes to three of them: Pedro Santamaria, Gines Morata and Pedro Ripoll. As you know all three presented their thesis on the same day.

The work on clonal analysis literally exploded when you came back to Spain, with several crucial discoveries in a matter of a few years.

Before my return to Madrid, I had spent 5 years abroad and during that time I was doing experiments. That means that when I came back, I had an inventory of questions ready and the tools to answer them. The productivity at that time was enormous. There were problems jumping from everywhere. It was a new world, a new way of seeing things, and the access to this new world immediately asked you for generalizing theories, for systematic thinking about what you were finding. We had to allocate the results in a new frame of thought.

\section{The end of the quest}

Coming back to an earlier question, that of the biased view, I recently had a discussion with C. Sotelo about whether Cajal's views were biased or not.

Tremendously biased! Cajal was a very intelligent person and with a very large perspective of things. When the cell theory started, the only exception was the nervous system and obviously he asked: Why should there be an exception? and he just started looking at cell discontinuities using the Golgi technique. For Cajal, neurons are cells a priori, he was convinced. He spent most of his life documenting this, in embryos, with comparative anatomy, and he demonstrated with time that neurons were indeed just individual cells. He was a model for all of us.

You had a similar bias about the role of genes in development. Was it already present at the time of your thesis?

No, absolutely not. I was just a member of a society where cells were simply blastemes, and genes were alleles, and nothing to it! I was born into this mentality. The discovery came in Caltech, that the genes, the wild type genes, do the job. The perturbations may help to understand the wild type function, but they are not interesting. These are convictions that are based not on intuition but on too much data pointing in the same direction and nothing that contradicts it - it's got to be right! I gave a seminar one of the last days I was there, under the title Lineages, cells and genes. These were the units to be dealt with, and development had to be explained in these terms. Among the audience was Max Delbrück, normally a 
severe critic of speakers, and he was enthusiastic about my talk.

I am still trying to get at the very origin of your singularity as a pioneer of developmental genetics. Could you define what was your state of mind before it all began?

None! It is the experience, the encountering of situations that have certain rules, certain constraints, certain logic, that shaped my state of mind. The moment you start finding resonance, there has got to be an invariant property. It's not a curiosity, it's not an accident - it's got to be right! The discovery of that logic is what brings you to take a prioripositions, mental positions from which you continue working.

In another interview (Mendez, 1999), you said that the idea that variety can be reduced to rules was not an intuition, but a few lines later in the same interview you say that it was one. Could you clarify?

[Silence] Well, it is an intuition... and a question. Now, why is it an intuition? This is the right question. I think it arises from a historical education. When you analyze history you do the same: history is contingent to some extent, but the same circumstances usually generate the same reactions, and revolutions are, in general, very similar to each other. The idea that there is some order in the world, that when things seem complicated, it may be because we have not analyzed them sufficiently, that there is something that is invariant, that there is modularity - this is a notion that I derived from the atmosphere of my house.

And this gave you the idea that even in events that seem very historical, very chaotic...

That there is order, there is order, yes I believe that. This is not an intuition, it is part of the atmosphere where you grow up, believing a priorithat things are susceptible to understanding with some rule. Yes, that is a notion I have had since I was very young. I like theoretical aspects of biology. I like them because those are the aspects where you can find order and justification. And then the associated question is, where did I get that? Well, look, I don't think it came from my father. My father was not a theorist. He was deeply embedded in historical or archeological reality. But my grandfather liked theory very much - he wrote several books on philology linguists and philologists look for order!

Philology is very close to the order of the brain, which, certainly, is a most ordered structure.

He liked to put in order, to find order.. The theoretical components that I have - and I believe that I have many, not necessarily good but still present - come from this educational inclination to find order. The conviction - it is not intuition, in the end, it is a conviction - that there is order, and that we simply have to discover it. Yes, this would be the summary of my life.

\section{A life of discoveries}

Could you summarize the major achievements of your career so far?

The cell dissociation-reassociation experiments, and the discovery of specificity in cell recognition, is one. It was very important, not because of the theoretical aspects, but because it opened a new way of looking at development as a whole. It also allowed me to start visualizing cells and cell properties.

Clonal analysis was a new way of looking at cells in a developmental context, and of defining numerical and temporal parameters. It allowed a quantitative assessment of growth properties at the cellular level, as well as an analysis of cell autonomy. This revealed that most developmental genes act in a cell-autonomous way, suggesting that development is mostly an intrinsic property of the cells. More than that, clonal analysis of morphogenetic mutants revealed that there are genes that are territorial genes, systemic genes, that was a fantastic change - mentally.

The discovery of compartments is also a very important one, as it points to a modular way of making development, and to the associated genes. It also led to the idea that if development is modular, then the genes associated with it must work in a combinatorial way, and to all the theory that goes behind. This turned out to be important, not only because of the discovery at the time, but because it has later been shown to be common to many developmental processes.

The analysis of lethals in mosaics was also an important progress. This was made possible by the development of clonal analysis. Before using clonal analysis, the only thing you could do with lethals is just to describe them histologically, describe what happens as the embryo is falling apart, and in many cases you could not even do that, because you did not have an embryo. Most lethal mutations act so early in development that they kill the organism from the very beginning. In the long run, lethal mutation analysis was probably the most productive application of clonal analysis theoretically. It was the one that led me to the most interesting conclusions in developmental genetics.

The idea that groups of genes, syntagmata, interact to define a developmental operation; this was not a discovery, it was a mental contraption. The moment you start analyzing transregulation in systems like, say, bithorax or achaete-scute, you start seeing that the genes are specifically related to each other and form what I would call a computer chip. Chips like these, and the operations they perform, have been invented hundreds of millions of years ago. They have been ready ever since, and have been used for particular purposes in particular moments of development.

Then another very important discovery, which I would say is still not perceived completely by our colleagues, is the problem of accommodation. When you have a mosaic, the mutant territory often produces changes in the surrounding territories. This is produced not by diffusion, not by non-autonomy, but because he system is continuously trying to generate a continuous landscape of positional values. This led me to the problem of entelechia - the attainment of final size and shape - and of growth control, which I am still working on.

\section{Reflections on the past and the future}

\section{Teaching and research}

Let me introduce your views about teaching with a quote Concepts cannot be transmitted; the student has to abstract them 

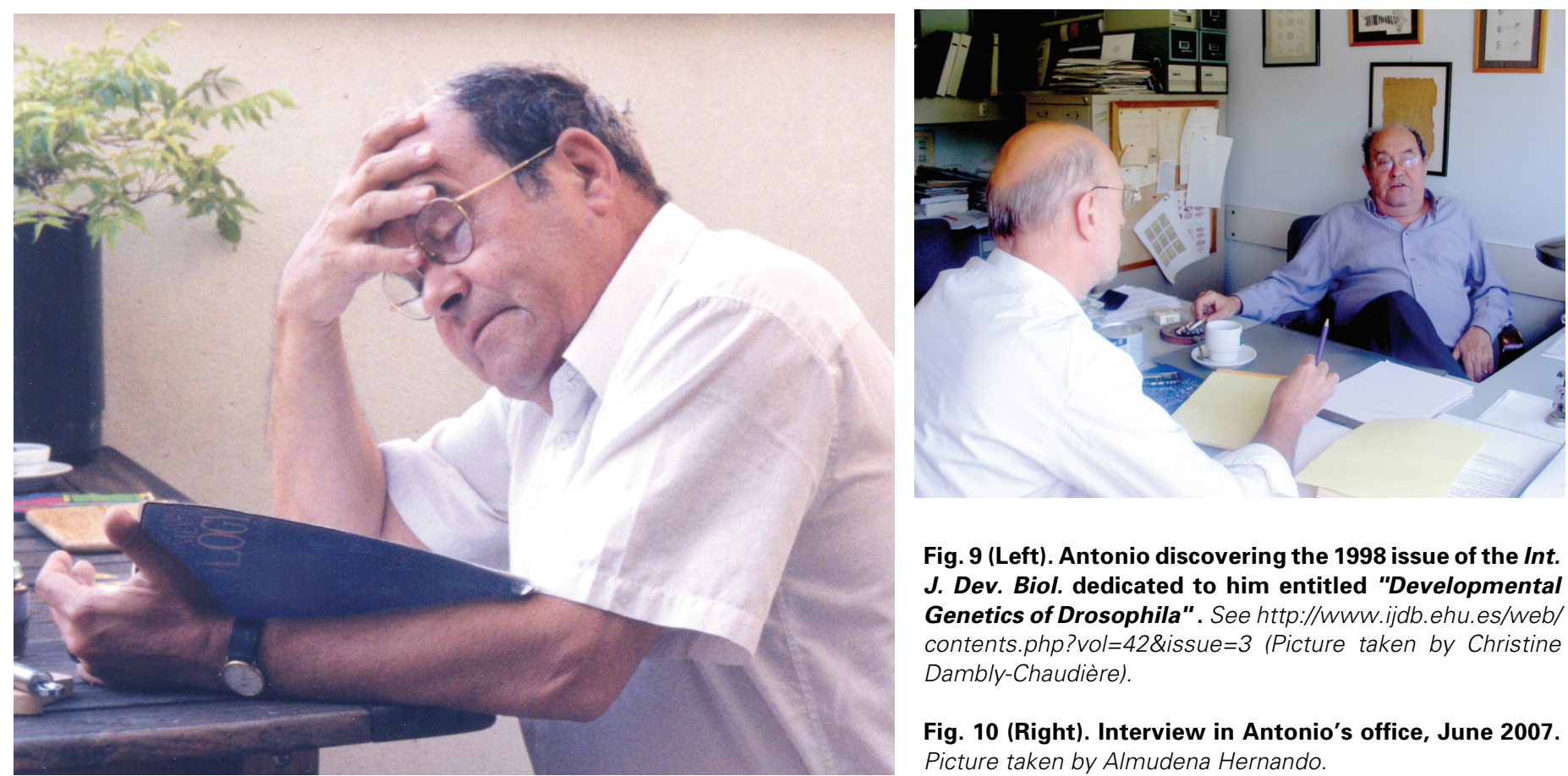

Fig. 9 (Left). Antonio discovering the 1998 issue of the Int. J. Dev. Biol. dedicated to him entitled "Developmental Genetics of Drosophila". See http://www.ijdb.ehu.es/web/ contents.php?vol=42\&issue $=3$ (Picture taken by Christine Dambly-Chaudière).

Fig. 10 (Right). Interview in Antonio's office, June 2007. Picture taken by Almudena Hernando.

himself by comparing attributes. This pedagogy comes naturally to professors that are well acquainted with the field they are teaching, and who have enthusiasm. I believe enthusiasm fits everywhere. Not only in art, history and philosophy, which are attractive because of their emotional component, but also in the seemingly drier scientific disciplines. Science must be presented for what it is: an adventure of thought. The student must read more than study, and think about what he reads more than learn it. It does not matter if his interpretation is wrong: further reading will correct it. (GarciaBellido, 1988).

\section{Would you agree that it is also important to help students open} their eyes to the world?

To open their eyes to the worldis too vague. You do not go to the world and learn or observe things just for the sake of it. You go to the world with questions first, and your work depends on the questions you put forth. The world is not structured: it is the mind of every one of us that organizes it. There is nothing such as a world in front of you that you will know by studying it. No, we are continuously interpreting.

This is what I meant by opening their eyes: realizing that you can ask questions about essentially everything.

Then I would agree. You educate yourself to ask - which is by the way the Greek way of educating. It's teaching you to ask. To ask yourself continuously why that? Not what for?, but rather why does it occur? This is a very important question. I think the best way to educate future researchers is to use the Socratic way, to try to get a statement and decompose, analyze, deconstruct the statement and ask which alternatives there are. This type of dialectic education is very stimulating.

What are the qualities you praise most in your own students? Motivation and ambition are two very important aspects. Ambition, not in the sense of being successful, or of obtaining some pretty or spectacular result, but the ambition of aiming at understanding things that are not immediately accessible. Things become interesting when you have licked them dry and what remains is of more universal value. And to reach this stage you have to be very motivated - even somewhat obsessed, as my father used to say , turning the questions around and around. Motivation is a desire, something that arises within you and reaches out rather blindly.

\section{Those are not rational qualities?}

But there is another aspect, which is also important. If motivation comes from a question a priori, that arose from your readings or from your experiments, fine; but if it also deals with the question of which of two questions is the most interesting, and why, then this is even better, because it reaches further. This is more rational. It says that some things are more important than others, and that in this life, we have to make choices. And in my view, the most important is that which is the most mysterious. This is what motivated the diaspora of molecular biologists when they abandoned bacteria and phages: the mystery of the brain.

But you have the counterexample of Driesch who obviously went to the most mysterious (the control of embryo size and shape) and failed completely.

You have to go to the most important... that can be solved! The problem of Driesch was that the solution to his question was not accessible with the tools he had at the time. It is not a question that you can solve by pricking the embryo. Maybe that was one of the reasons why I liked genetics, because I knew that, one way or another, it dealt with entities that were inheritable and that were part of evolution. This was indeed an intuition, but an intuition based on culture, on readings, on extrapolation.

Don't you think that very often when we ask a question, we 


\section{already have an answer?}

Yes, sure. This is a dialog. You ask questions because you think that there is possibly an answer to them, and the answer is in the inventory of things you know - it must be! The role of the individual, its education, its memories, the society he belongs to, and so on, is crucial. When we explore the world, we don't go into an empty space. You are asking things because you have an interest in them, and you have an interest in them because you may have some type of answer to begin with. We are not learning from nothing. We are proposing things to order the world with respect to our own memories, our experience.

Sometimes we are very proud of results that gain little recognition. Did you often have that feeling?

I would have to make a confession: my feeling is that most of my work was not understood when I was presenting it, and so I am kind of accustomed to that. The gynandromorphs, the compartments... people were not prepared. They thought you cannot have this order that you propose, it cannot be that the system has an internal logic. This is contrary to our expe-

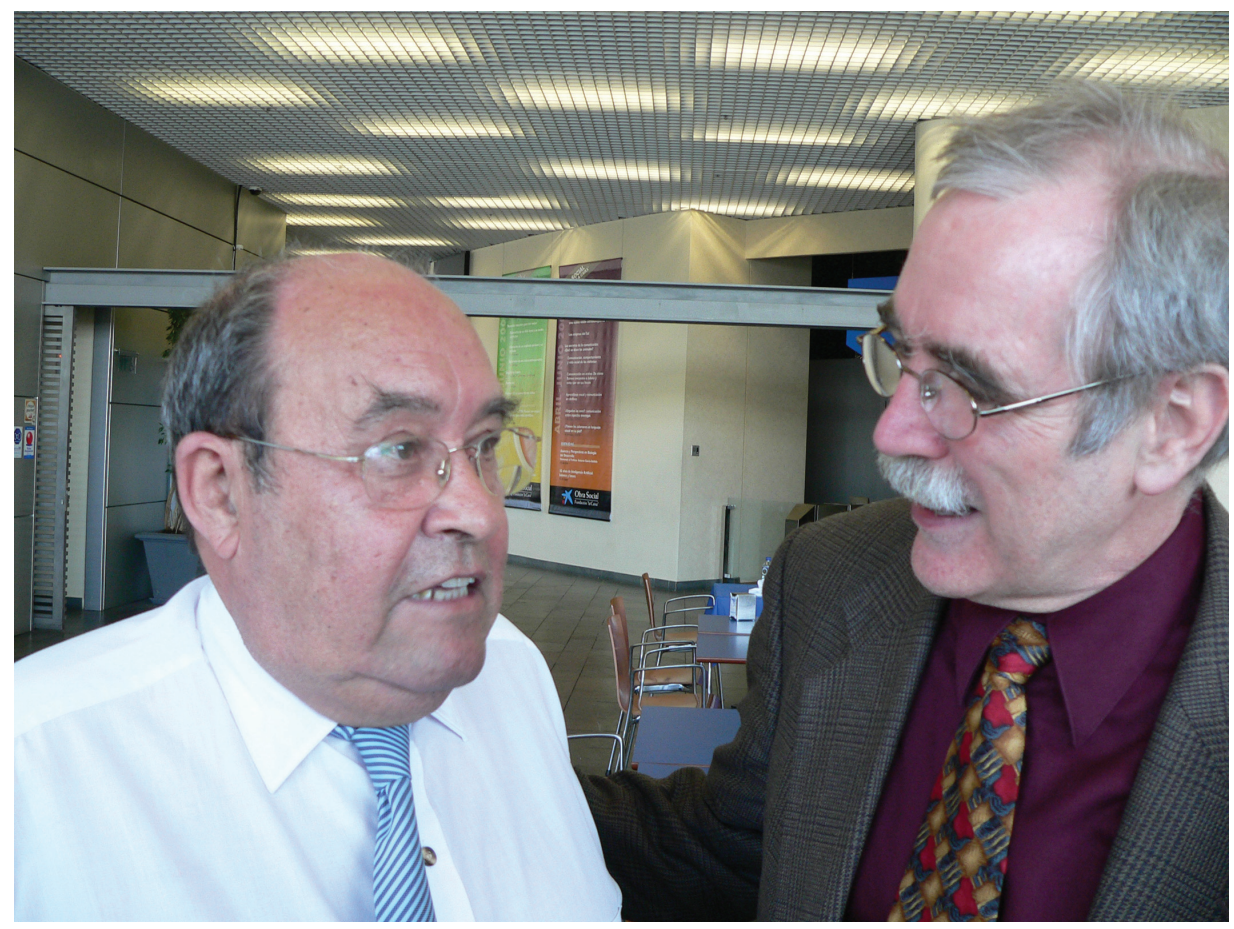

Fig. 11. With Eric Wieschaus at the Garcia-Bellido hommage workshop held in Madrid in April 2006. Upon seeing this picture Eric commented "A great picture, Antonio especially - like he's simultaneously arguing for and thinking through some serious biological controversy, one that is no longer so controversial to him.." Picture taken by Igor Zhimulev.

rience of the variety of nature, of the continuity of the parameters of nature. I have a very long experience of this lack of understanding. But this may have its advantages. To find and analyze things which may open the way to something new - this is something you can only do when you are a little bit isolated. And I think that the isolation of Madrid was a tremendous help for me.

The problems you examined changed over time. Were there specific reasons for each change?

There is a moment when you have seen the answer, not in detail - because this you will never do - but you have seen it. This is the reason why I left bithorax and the regulators of bithorax and all that. It was already an established field, and then achaete-scute. You go to other questions because they call you, because there is a mystery over there. This also is a motivation in the original meaning of the word, that is, it is something that moves you. It is not curiosity - it is theoretical interest. But I think that people in general are less interested in ideas now - what matters to people are the data! There are so many things to be described, the techniques are so powerful that they think first let's describe and then we will see. We will leave the ideas for a big computer to spit them out.

\section{Development}

You are not too fond of the expression paradigm shift because it has been overused, yet this is exactly what you achieved in developmental biology

The goals in science - and in particular in biology - have changed over the course of time. The problem associated with this change is to define what you want to understand, and in terms of what do you want to understand it. Biology has a long history of pure description, which is not to be despised: first make an inventory of what we do want to know. There were several breakthroughs though. The discovery of cells as units of all living beings was one, and with it the analysis of gametes and of chromosomes, and later on, the discovery of hereditary factors as discontinuous elements that take care of certain characteristics. Finally, the fantastic work of enzymology, the process of changing one molecule into another and the notion that very similar enzymes are present in all organisms.

After the structure of DNA and the genetic code were elucidated, a number of people considered that the next frontier was not development or evolution, but rather, the brain.

At the beginning of the 20th century, there was the notion that you have genes that code for enzymes. Then you have metabolism, and this metabolism is very conserved. Evolution and development was left as the extrapolation of things that you would know when you analyze the metabolism of a cell, or the physiology of the gut, there was nothing more to explain. This mentality reached all the way up to the discovery of DNA. DNA was the extreme abstraction, once you have the DNA, then you have the molecular biology, DNA transcription and translation in proteins. You find invariants of certain triplets that code for particular amino acids, and all the machinery of protein synthesis. At that time, it started to become clear that variation could have the form of a change of one amino acid as shown by the work on hemoglobin. This led to the notion that there was nothing profound to be said in biology, nothing causal to be found, simply the description of these 
accidents that led to this morphology or to this physiology. Development is the consequence of a multiple interaction, a cascade of reactions, and variation results from a change of amino acids that modifies the $\mathrm{Km}$ of an enzyme. This is the mentality that was around when I started, when I was a student. There was nothing very mysterious to explain, there was no problem. This is the time of the diaspora of people like Crick, Brenner, Benzer, Streisinger, Stent and many others: they wanted to go to the nervous system because this is still a mystery.

\section{What do you think was the turning point for the new rise of developmental biology?}

A major factor was the operon discovery, and with it, the notion that some genes talk with other genes, which I would say is the main, or one of the main, discoveries of the century. With this discovery came the notion that the genome is not something that is deployed along development with a logic of certain reactions leading to other reactions, but may have its own logic. The mentality that the whole system is controlled from within, that it is an internal problem: that, I think, was a change in paradigm. We understand now how the specific sequence of a gene encodes the structure of a protein, how the structure provides shape and from this shape comes the capability to recognize specific molecules - to talk to other players.

\section{What are the major challenges now?}

The change in perspective, from external to internal causality, still has not reached other systems. For example we still believe that in development, morphogens are deciding, that you have an entity with certain receptors, and you get a signal; then the cells change completely their behavior. This mentality still operates because too little emphasis is put on the local aspects, the properties of the responding cells, the identity of the cells,

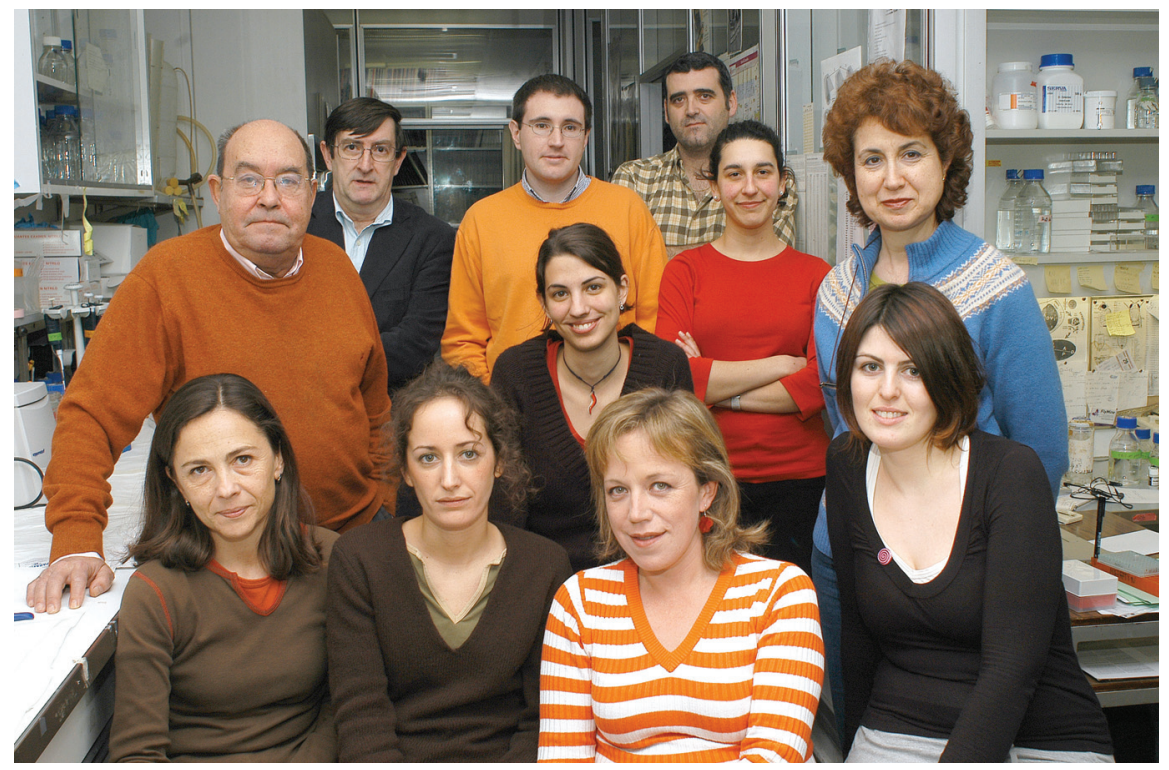

Fig. 12. Antonio's group today in the Universidad Autónoma de Madrid, Spain. Standing (from left to right): Antonio García-Bellido, Juan F. Santarén, Luis Alberto Baena-López, Antonio Baonza, Jana Alonso and Rosario Hernández. Sitting (from left to right): Ana López-Varea Cristina Cruz, Sandra Díaz García (middle), Almudena Hernando and Beatriz Pérez Sanjuan. the sophistication of the inventory of cell reactions, which are obviously controlled by genes. The role of morphogens is something we are dealing with recently in my lab, and we see that size and shape are not determined by something coming from somewhere outside. Morphogens are just growth factors which are needed by the machine to continue, but they are not providing specificity, the specificity is provided from within. And we still do not know how it is controlled.

\section{Evolution}

You do not give to adaptive selection as much importance as Darwin did.

For Darwin, the external world was very powerful in deciding, but we are changing the perspective, we are changing the framework that we think is relevant to what we want to explain. Evolution, the more we look to it, the more it becomes just a problem of development. The notion of adaptation, for example, in evolution, this was something that explained everything and did not explain much. This change in perspective goes close to the notion of the antibodies not being the result of adaptation to the shape of the antigen, but being a proposition which can be checked later on by the immune reaction: the logic is not in the antigen, it's in the antibody.

\section{In evolution too, do you think that the cellular level may be} the most relevant?

I think we are more and more interested in the ways cells behave, in the way cells perform. The behavior of cells obviously is controlled by the active genes within them, but we still have problems which are unsolved, problems such as how do you control the size of a population, namely the size of an organ, or the shape of an organ, the problems are there and they are very old in fact. Then the problem is, what type of propositions can genes make about development? How do they define the performance of cells? How much do we know about the proposition aspect of genes?

Your idea is that internal adaptation is at least as important as external adaptation. I think we are getting closer and closer to the notion of an internal control. The whole chapter of cell behavior, the rules of the game, the combinatorial of gene groups, of genetic operations, the repetition of gene actions and gene groups in different parts of the organism, the control of the time when these things happen, the control of where they do happen, these are invariant properties but they can lead to a fantastic variety - within limits! Because the thing you cannot break obviously is that molecules must recognize each other. The necessity to preserve molecular recognition is a tremendous constraint, and a key element of evolution.

Don't you think that developmental genetics has had only a minimal impact on evolution so far? 
No. Now it's beginning a lot, with comparative genetics. Few people are doing that, true, but they are very relevant people. They are the pioneers and they will get to the core of the problem. Not people working on population genetics, that was a failure. The notion that variation is due to changes in the amino-acid sequence, that led to the electrophoretic analysis and so on, this is gone. We know now that most of the relevant variation is in the enhancer regions, with completely different alteration mechanisms and a fantastic DNA turnover. But gene comparisons are very difficult. The variations are so large that it is difficult to find rules and say aha! This variation is associated with this type of change!

\section{The brain}

The major determinant of brain organization was long thought to be plasticity, that is, adaptation to the external world.

There was a time - I have lived this time and you too - when the nervous system was a matter of control of cAMP or calcium pumps. If you have these elements you have the fundamentals of the problem. Cell projections, target recognition; these are things that we know are important, and indeed very relevant, but they came to light only more recently. Maybe we didn't have the tools; we had the question but not the way of attacking it. I think many things in biology have been explained by things outside - the fact that the organism is in a complex world somehow has led to the idea that it is the complexity of the external world that decides the complexity of the organism. But now, I think we are learning, at last, that there are many more internal constraints and limitations in what the organism can do.

One of the most evanescent products of the brain is the feeling of beauty. It is difficult to imagine that it has been selected for, and one is left with the idea that it is a normal product of the development of brain complexity.

The perception of beauty is so variable that you lose any feeling of what the real bases of it are. But this variation is superficial. At a deeper level, I think that esthetics is universal. I would incline myself to your second explanation, that the feeling of beauty is a by-product of the way the system perceives and finds enjoyment in certain feelings like eating - no doubt -, in music and in other types of perception. Then, on top of it, is memory, and on top of that, is conscience. Conscience glues the whole thing together and with certain elements that are references of the different cultures. The outcome is that, in the long run, there is an enjoyment in certain perceptions - what we call beauty.

\section{In maths and physics, people are often said to appreciate the} beauty of an equation, do you have any sense of that in biology?

No, biology is too historical. The thing that is at the core of biology is molecular recognition; that is what maintains the building. I don't think beauty can be used - it can be used for personal enjoyment, the decorative aspects of different organisms. Going on safari and seeing lions... but I do not think it produces anything in science, and for sure not in developmental biology. It's just variation. The moment we know the rules for variation, then we start loosing interest in the particular cases.

\section{How do you think the brain can produce discoveries?}

We commented earlier that a scientist has to be somewhat obsessed, preoccupied, turning his problem around and around. Maybe we will never know what happens then, but I am of the opinion that when you plant a problem in the brain - not in a conscious way, but subconsciously - the system tries to look for correct connections to solve this problem, and keeps trying in all directions. If no solution is found today, then it will come tomorrow. An obsession has this advantage that it helps to maintain the system in this searching status for long periods!

\section{Acknowledgments}

I thank Almudena Hernando for support and help, Mike Bate, Diego Garcia-Bellido Capdevila and Christine Dambly-Chaudière for comments on earlier versions of this manuscript, and also the INSERM (Institut National de la Santé et de la Recherche Médicale), ARC (Association pour la Recherche sur le Cancer) and ANR (Agence Nationale de la Recherche) for generous support.

\section{References}

ALBERTO BAENA-LÓPE, L. and ANTONIO GARCÍA-BELLIDO, A. (2003). Genetic requirements vestigial in the regulation of Drosophila wing development. Development 130: 197-208.

AZNAREZ, M. (2006) Un científico iconoclasta. El Pais, 10 Sept.

BAENA-LOPEZ, L. A., BAONZA, A. and GARCIA-BELLIDO, A. (2005). The orientation of cell divisions determines the shape of Drosophila organs. Curr. Biol. 15: 1640-1644.

BAENA-LOPEZ, L. A. and GARCIA-BELLIDO, A. (2006). Control of growth and positional information by the graded vestigial expression pattern in the wing of Drosophila melanogaster. Proc. Natl. Acad. Sci. USA 103: 13734-13739.

BAONZA, A. and GARCÍA-BELLIDO, A. (2000). Notch signaling directly controls cell proliferation in the Drosophila wing disc. Proc. Natl. Acad. Sci. USA 97: 2609-2614.

BAONZA, A, DE CELIS J.F. and GARCÍA-BELLIDO, A. (2000). Relationships between extramacrochaetae and Notch signalling in Drosophila wing development. Development 127: 2383-2395.

BOTAS, J., MOSCOSO DEL PRADO, J. and GARCÍA-BELLIDO, A. (1982). Genedose titration analysis in the search of trans-regulatory genes in Drosophila. EMBO J. 1: 307-310.

BOTAS, J., CABRERA, C.V. and GARCÍA-BELLIDO, A. (1988). The reinforcementextiction process of selector gene ancivity: a positive feed-back loop and cellcell interactions in Ultrabithorax patterning. Roux's Arch. Dev. Biol. 197: 424434.

CABRERA, C.V., BOTAS, J. and GARCíA-BELLIDO, A. (1985) Distribution of Ultrabithorax proteins in mutants of Drosophila bithorax complex and its transregulatory genes. Nature 318: 569-571.

CAPDEVILA, M.P. and GARCÍA-BELLIDO, A. (1974). Development and genetic analysis of bithorax phenocopies in Drosophila. Nature 250: 500-502.

CAPDEVILA, M.P. and GARCÍA-BELLIDO, A. (1978). Phenocopies of bithorax mutants: genetic and developmental analyses. Roux's Arch. Dev. Biol. 185: 105-126.

CAPDEVILA, M.P. and GARCÍA-BELLIDO, A. (1981). Genes involved in the activation of the Bithorax complex of Drosophila. Roux's Arch. Dev. Biol. 190: 339-350.

CAPDEVILA, M.P., BOTAS, J. and GARCÍA-BELLIDO, A. (1986). Genetic interactions between the Polycomb locus and the Antennapedia and Bithorax complexes of Drosophila. Roux's Arch. Dev. Biol. 195: 417-432.

CASTELLI-GAIR, J.E. and GARCÍA-BELLIDO, A. (1990). Interactions of Polycomb and trithorax with cis regulatory regions of Ultrabithorax during the development of Drosophila melanogaster. EMBO J. 9: 4267-4275.

CIFUENTES, F. J. and GARCÍA-BELLIDO, A. (1997). Proximo-distal specification in the wing disc of Drosophila by the nubbin gene. Proc. Natl. Acad. Sci. USA 
94: 11405-11410.

DE CELIS, J. F., MARÍ-BEFFA. M. AND GARCÍA-BELLIDO, A. (1991). Function of trans-acting genes of the achaete-scute complex in sensory organ patterning in the mesonotum of Drosophila. Roux's Arch. Dev. Biol. 200: 64-76.

DE CELIS, J.F., MARÍ-BEFFA, M. and GARCÍA-BELLIDO, A. (1991). Cell-autonomous role of Notch, an epidermal growth factor homologue, in sensory organ differentiation in Drosophila. Proc. Natl. Acad. Sci. USA 88: 632-636.

DE CELIS, J.F., BARRIO, R., DEL ARCO, A. and GARCÍA-BELLIDO, A. (1993). Genetic and molecular characterization of a Notch mutation in its Delta- and Serrate-binding domain in Drosophila. Proc. Natl. Acad. Sci. USA 90: 40374041.

DE CELIS, J.F. and GARCÍA-BELLIDO, A. (1994). Roles of the Notch gene in Drosophila wing morphogenesis. Mech. Dev. 46: 109-122.

DE CELIS, J.F., GARCÍA-BELLIDO, A and BRAY, S.J. (1996). Activation and function of Notch at the dorsal-ventral boundary of the wing imaginal disc. Development 122: 359-369.

DE CELIS, J.F., GARCÍA-BELLIDO, A and BRAY, S.J. (1997). Notch signalling regulates veinlet expression and establishes boundaries between veins and interveins in the Drosophila wing. Development 124: 1919-1928.

DÍAZ-BENJUMEA, F.J., GONZÁLEZ-GAITÁN, M.A. and GARCÍA-BELLIDO, A. (1989). Developmental genetics of the wing vein pattern of Drosophila. Genome 31: 612-619.

DÍAZ-BENJUMEA, F.J. and GARCÍA-BELLIDO, A. (1990). Genetic analysis of the wing vein pattern of Drosophila. Roux's Arch. Dev. Biol. 198: 336-354. (95)

DÍAZ-BENJUMEA, F.J. and GARCÍA-BELLIDO, A. (1990). Behaviour of cells mutant for an EGF receptor homologue of Drosophila in genetic mosaics. Proc. R. Soc. Lond. B 242: 36-44.

EXTAVOUR, C. and GARCÍA-BELLIDO, A. (2001). Germ cell selection in genetic mosaics in Drosophila melanogaster. Proc. Natl. Acad. Sci. USA 98. 1134111346.

FERNÁNDEZ -FÚNEZ, P. CHENG-HSIN LU, RINCÓN-LIMAS, D., GARCÍABELLIDO, A. and BOTAS, J. (1998). The relative expression amounts of apterous and its co-factor $\mathrm{dLdb} / \mathrm{Chip}$ are critical for dorso-ventral compartmentalization in Drosophila wing. EMBO J. 17: 6846-6853.

FERRÚS, A. and GARCÍA-BELLIDO, A. (1976). Morphogenetic mutants detected in mitotic recombination clones. Nature 260: 425-426.

GARCÍA-BELLIDO, A. (1962). Correlations between cytological stages of the spermatogenesis of Drosophila melanogaster and their sensitivity to x-rays. Dros. Inf. Serv. 36: 63-65.

GARCÍA-BELLIDO, A. (1962). Fenogenética del locus furrowed (fw) de Drosophila melanogaster. Thesis de doctorado. Universidad Complutense de Madrid.

GARCÍA-BELLIDO, A. (1963). Fenogenética del locus «furrowed» (Fw) de Drosophila melanogaster. I. Especificidad del síndrome pleitrópico. Genética Ibérica 15: 1-74.

GARCÍA-BELLIDO, A. (1963). Fenogenética del locus «Furrowed» (Fw) de Drosophila melanogaster. II. Influencia del medio genotípico sobre la manifestación del síndrome. Genética Ibérica 15: 75-102.

GARCÍA-BELLIDO, A. (1964). Das Sekret der Paragonien als Stimulus der Fekunditàt bei Weibchen von Drosophila melanogaster. Zeitsch. Naturforschung19b: 491495.

GARCÍA-BELLIDO, A. (1965). Larvalentwicklung transplantierter Organe von Drosophila melanogaster im Adultmilieu. J. Ins. Physiol. 11: 1071-1078.

GARCÍA-BELLIDO, A. (1966). Pattern reconstruction by dissociated imaginal disk cells of Drosophila melanogaster. Dev. Biol. 14: 278-306.

GARCÍA-BELLIDO, A. (1966) Changes in selective affinity following transdetermination in imaginal disc cells of Drosophila melanogaster. Expt/. Cell Res 44: 362-392.

GARCÍA-BELLIDO, A. (1967). Histotypic reaggregation of dissociated imaginal disc cells of Drosophila melanogaster cultured in vivo. Roux's Arch. Dev. Biol. 158: 212-217.

GARCÍA-BELLIDO, A. (1968). Cell affinities in antennal homoeotic mutants of Drosophila melanogaster. Genetics 59: 487-499.

GARCÍA-BELLIDO, A. (1968). Cell lineage in the wing disc of Drosophila melanogaster. Genetics 60: 181.
GARCÍA-BELLIDO, A. and MERRIAM, J.R. (1968). Bristles or hairs: the cell heredity of a genetic decision in Drosophila melanogaster. Proc. Natl. Acad. Sci. USA 61: 1147

GARCÍA-BELLIDO, A. and MERRIAM, J.R. (1969). Cell lineage of the imaginal discs in Drosophila gynandromorphs. J. Exp. Zool. 170: 61-76.

GARCÍA-BELLIDO, A. and MERRIAM, J.R. (1971). Parameters of the wing imaginal disc development of Drosophila melanogaster. Dev. Biol. 24: 61-87.

GARCÍA-BELLIDO, A. and MERRIAM, J.R. (1971). Genetic analysis of cell heredity in imaginal discs of Drosophila melanogaster. Proc. Natl. Acad. Sci. USA 68: 2222-2226.

GARCÍA-BELLIDO, A. (1972). Pattern Formation in Imaginal Disks. In Results and Problems in Cell Differentiation. Vol. 5, pp.59-91. (H. Ursprung, R. Nöthiger, eds.) Springer-Verlag. Berlin.

GARCÍA-BELLIDO, A.and SANTAMARÍA, P. (1972). Developmental analysis of the wing disc in the mutant engrailed of Drosophila melanogaster. Genetics 72: 87-104.

GARCíA-BELLIDO, A., RIPOLL, P. and MORATA, G (1973). Developmental compartmentalization of the wing disk of Drosophila. Nature New Biol. 245: 251 253.

GARCÍA-BELLIDO, A. and DAPENA, J. (1974). Induction, detection and characterization of cell differentiation mutants in Drosophila. Molec. Gen. Genet. 128: 117-130.

GARCÍA-BELLIDO, A. (1975). Genetic control of wing disc development in Drosophila. In: Cel/ Patterning. Ciba Foundation Symposium 29, pp. 161-182. Elsevier, Amsterdam.

GARCÍA-BELLIDO, A. and LEWIS, E.B. (1976). Autonomous cellular differentiation of homeotic bithorax mutants of Drosophila melanogaster. Dev. Biol. 48: 400 410.

GARCÍA-BELLIDO, A. and NÖTHIGER, R. (1976). Maintenance of determination by cells of imaginal discs of Drosophila. Roux's Arch. Dev. Biol. 180: 189-206.

GARCÍA-BELLIDO, A. (1977). Inductive Mechanisms in the Process of Wing Vein Formation in Drosophila. Roux's Arch. Dev. Biol. 182: 93-106.

GARCÍA-BELLIDO, A. (1977). Homoeotic and atavic mutations in insects. Amer Zool. 17: 613-629.

GARCÍA-BELLIDO, A., and RIPOLL, P. (1978). The number of genes in Drosophila melanogaster. Nature 273: 399-499.

GARCÍA-BELLIDO, A. and SANTAMARÍA, P. (1978). Developmental analysis of the achaete-scute system of Drosophila melanogaster. Genetics 88: 469-486

GARCÍA-BELLIDO, A and. CAPDEVILA, M.P. (1978). The initiation and maintenance of gene activity in a Developmental pathway of Drosophila. In The clonal basis of development. vol.7, pp.3-21. (S. Subtelny and I.M. Sussex, eds.) Academic Press, New York.

GARCÍA-BELLIDO, A. and MOSCOSO DEL PRADO, J. (1979). Genetic analysis of maternal information in Drosophila. Nature 278: 346-348.

GARCÍA-BELLIDO, A. (1979). Genetic analysis of the achaete-scute system of Drosophila melanogaster. Genetics 91: 491-520.

GARCÍA-BELLIDO, A. (1980). Opening Remarks. In Development and Neurobio/ogy of Drosophila. pp. 1-2 (O. Siddiqui, P. Babu, J. Hall and L. Hall, eds.) Plenum Press.

GARCÍA-BELLIDO, A. (1981). From the Gene to the Pattern: Chaeta Differentiation. In Cellular controls in differentiation, pp. 281-304. (C.W. Lloyd and D.A. Rees, eds.) Academic Press.

GARCÍA-BELLIDO, A. (1982). The bithorax syntagma. In Advances in Genetics, Development, and Evolution of Drosophila. VII European Drosophila Research Conference. pp. 135-148. (S. Lakovaara, ed.) Plenum Press.

GUBB, D. and GARCíA-BELLIDO, A. (1982). A genetic analysis of the determination of cuticular polarity during development in Drosophila melanogaster. $J$. Embryol. Exp. Morph. 68: 37-57.

GARCÍA-BELLIDO, A. (1983). Comparative anatomy of cuticular patterns in the Genus Drosophila. In Development and Evolution, pp. 227-255. (B.C. Goodwin, N. Holder and C.C. Wylue, eds.) Cambridge University Press.

GARCÍA-BELLIDO, A. (1984). Hacia una Gramática Genética. Discurso de Ingreso en la Real Academia de Ciencias Exactas, Físicas y Naturales.

GARcíA-BELlidO, A. (1985). Cell lineages and genes. Phil. Trans. R. Soc. 
London. B 312: 101-128.

GARCÍA-BELLIDO, A. (1988) Reflexiones al borde del camino sobre la investigacion en Biologia. In Horizonte Cientifico en Espana, ed. H. Meinke. Circulo de Lectores.

GARCÍA-BELLIDO, A. and DE CELIS, J.F. (1992). Developmental genetics of the venation pattern of Drosophila. Annu. Rev. Genet. 26: 275-302.

GARCíA-BELLIDO, A. (1993). Coming of age. Trends Genet. 9: 102-103.

GARCÍA-BELLIDO, A. (1994). How organisms are put together. European Review 2: $15-21$.

GARCÍA-BELLIDO, A., CORTÉS, F. AND MILÁN, M. (1994). Cell interactions in the control of size in Drosophila wings. Proc. Natl. Acad. Sci. USA91: 10222-10226.

GARCíA-BELLIDO, A. (1996). Symmetries throughout organic evolution. Proc. Natl. Acad. Sci. USA 93: 14229-12232.

GARCíA-BELLIDO, A. (1997). Developmental Genetics and Evolution. Plenary lectures, Acad. Sci. USA.

GARCÍA-BELLIDO, A. (1997). Paradigm Shifts in Developmental Biology. Taniguchi Symposium on Developmental Biology IX. «Developmental Biology Half a Century». April, 6-9, 1997. Kyoto. Japan.

GARCÍA-BELLIDO, A. (1998) The Engrailed Story. In Perspectives. Anecdotal, Historical and Critical Commentaries on Genetics. Eds. J.F. Crow and W.F. Dove. Genetics 148: 559-544.

GARCÍA-BELLIDO, A.C. and GARCÍA-BELLIDO, A. (1998) Cell proliferation in the attainment of constant sizes and shapes: the Entelechia model. Int. J. Dev. Biol. 42: 353-362.

GARCÍA-BELLIDO, A. (1999). Los Genes del Cámbrico. Discurso Inaugural del Año Académico 1999-2000. 27 de Octubre de 1999. Real Academia de Ciencas Exactas, Físicas y Naturales.

GONZALEZ-GAITAN, M., CAPDEVILA, M. P. and GARCÍA-BELLIDO, A. (1994). Cell proliferation patterns in the wing imaginal disc of Drosophila. Mech. Dev. 40: 183-200.

HADORN, E. and GARCÍA-BELLIDO A. (1964). Zur proliferation von Drosophila Zellkulturen im Adultmilieu. Rev. Suisse Zool. 71: 576-582.

HADORN, E. and GARCÍA-BELLIDO A. (1964). Zur proliferation von Drosophila Zellkulturen im Adultmilieu. Rev. Suisse Zool. 71: 576-582.
HADORN, E. and GARCIAA-BELLIDO A. (1964). Zur proliferation von Drosophila Zellkulturen im Adultmilieu. Rev. Suisse Zool. 71: 576-582.

MARTÍN-BLANCO, E., PASTOR-PAREJA J.C. and GARCÍA-BELLIDO, A. (2000). JNK and decapentaplegic signaling control adhesiveness and cytoskeleton dynamics during thorax closure in Drosophila. Proc. Natl. Acad. Sci. USA 97: 7667-8192.

MENDEZ, J. (1999) Antonio Garcia-Bellido: «Soy un experimentador al que le gusta teorizar». Revista de la Residencia de Estudiantes 7: 3-8. Appendix: selected publications of A. García-Bellido.

MICOL, J.L., CASTELLI-GAIR, J.E. and GARCÍA-BELLIDO, A. (1990). Genetic analysis of transvection effects involving cis-regulatory elements of the Drosophila Ultrabithorax gene. Genetics 126: 365-373.

MILÁN, M., CAMPUZANO, S. and GARCÍA-BELLIDO, A. (1996). Cell cycling and patterned cell proliferation in the wing primordium of Drosophila. Proc. Nat/. Acad. Sci. USA 93: 640-645.

MILÁN, M., CAMPUZANO, S. and GARCÍA-BELLIDO, A. (1996). Cell cycling and patterned cell proliferation in the Drosophila wing during metamorphosis. Proc. Natl. Acad. Sci. USA 93: 11687-11692.

MILÁN, M., CAMPUZANO, S. and GARCÍA-BELLIDO, A. (1997). Developmental parameters of cell death in the wing disc of Drosophila. Proc. Natl. Acad. Sci. USA 94: 5691-5696.

MORATA, G. and GARCÍA-BELLIDO, A. (1976). Developmental analysis of some mutants of the bithorax system of Drosophila. Roux's Arch. Dev. Biol. 179: 125143.

MOSCOSO DEL PRADO, J. and GARCÍA-BELLIDO, A. (1984). Cell interactions in the generation of chaetae pattern in Drosophila. Roux's Arch. Dev. Biol. 193 246-251.

PASTOR-PAREJAN J.C., GRAWE, F., MARTÍN-BLANCO, E. and GARCÍABELLIDO, A. (2004) Invasive cell behaviour during Drosophila imaginal disc eversion is mediated by the JNK signaling cascade. Dev. Ce//7: 387-399.

RESINO, J., SALAMA-COHEN, P. and GARCÍA-BELLIDO, A. (2002). Determining the role of patterned cell proliferation in the shape and size of the Drosophila wing. Proc. Natl. Acad. Sci. USA I: 502-7507

RIPOLL, P. and GARCÍA-BELLIDO, A. (1973). Cell Autonomous lethals in Drosophila melanogaster. Nature New Biol. 241: 15-16.

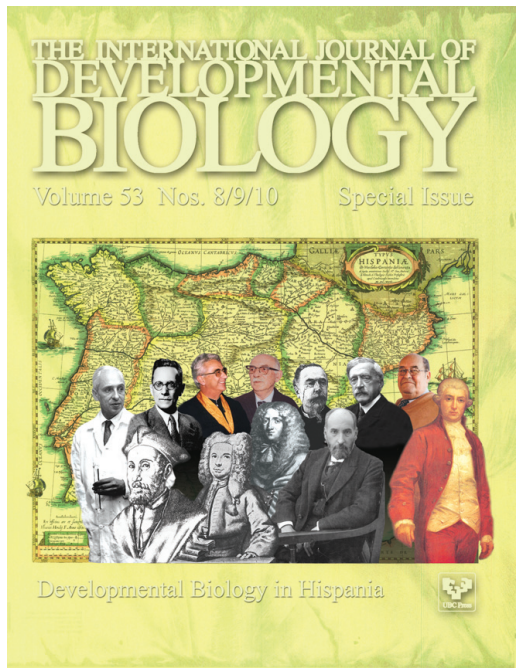




\section{Further Related Reading, published previously in the Int. J. Dev. Biol.}

See our Special Issue Fertilization, in honor of David L. Garbers and edited by Paul M. Wassarman and Victor D. Vacquier at: http://www.ijdb.ehu.es/web/contents.php?vol=52\&issue=5-6

See our Special Issue Developmental Genetics of Drosophila, in honor of Antonio García-Bellido and edited by Alain Ghysen at: http://www.ijdb.ehu.es/web/contents.php?vol=42\&issue=3

5th Congress of the Spanish Society of Developmental Biology

Jaume Baguñà

Int. J. Dev. Biol. (2007) 51: 91-96

In defense of pure science: Antonio García-Bellido.

F C Kafatos

Int. J. Dev. Biol. (1998) 42: 539-540

The genetic logic of Antonio García-Bellido.

G A Dover

Int. J. Dev. Biol. (1998) 42: 535-538

Antonio García-Bellido in Caltech.

E B Lewis

Int. J. Dev. Biol. (1998) 42: 523-524

Antonio García-Bellido at Hadorn's laboratory in Zurich.

R Nöthiger

Int. J. Dev. Biol. (1998) 42: 519-521

Debatable issues. Interview with L Wolpert and A García-Bellido.

Alain Ghysen

Int. J. Dev. Biol. (1998) 42: 511-518

Implications of the spatial and temporal regulation of Hox genes on development and evolution.

J Castelli-Gair

Int. J. Dev. Biol. (1998) 42: 437-444

From selectors to realizators.

$\mathrm{J}$ Pradel and R A White

Int. J. Dev. Biol. (1998) 42: 417-421

Cell proliferation in the attainment of constant sizes and shapes: the Entelechia model. A C García-Bellido and A García-Bellido

Int. J. Dev. Biol. (1998) 42: 353-362

Compartment boundaries: where, why and how?

$J$ P Vincent

Int. J. Dev. Biol. (1998) 42: 311-315

The development of concepts on development-a dialogue with Antonio García-Bellido.

Enrique Cerdá-Olmedo

Int. J. Dev. Biol. (1998) 42: 233-236

Antonio and Sturt: an interaction

J Merriam

Int. J. Dev. Biol. (1998) 42:525-528

An exceptional friend

$\mathrm{F}$ Jacob

Int. J. Dev. Biol. (1998) 42:529-530

Serendipity, the principle of limited sloppiness, and neural development YN Jan and LY Jan

Int. J. Dev. Biol. (1998) 42:531-534



5 yr ISI Impact Factor $(2008)=3.271$



